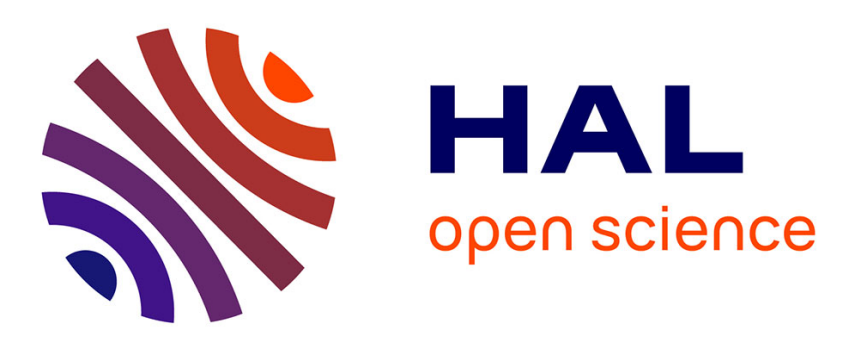

\title{
Variation in log quality and prediction of sawing yield in oak wood (Quercus robur)
}

Guillermo Riesco Muñoz, Andrés Remacha Gete, Manuel Gasalla Regueiro

\section{To cite this version:}

Guillermo Riesco Muñoz, Andrés Remacha Gete, Manuel Gasalla Regueiro. Variation in log quality and prediction of sawing yield in oak wood (Quercus robur). Annals of Forest Science, 2013, 70 (7), pp.695-706. 10.1007/s13595-013-0314-8 . hal-01201515

\section{HAL Id: hal-01201515 \\ https://hal.science/hal-01201515}

Submitted on 17 Sep 2015

HAL is a multi-disciplinary open access archive for the deposit and dissemination of scientific research documents, whether they are published or not. The documents may come from teaching and research institutions in France or abroad, or from public or private research centers.
L'archive ouverte pluridisciplinaire HAL, est destinée au dépôt et à la diffusion de documents scientifiques de niveau recherche, publiés ou non, émanant des établissements d'enseignement et de recherche français ou étrangers, des laboratoires publics ou privés. 


\title{
Variation in log quality and prediction of sawing yield in oak wood (Quercus robur)
}

\author{
Guillermo Riesco Muñoz • Andrés Remacha Gete • \\ Manuel Gasalla Regueiro
}

Received: 9 April 2013 / Accepted: 1 July 2013 / Published online: 26 July 2013

(C) INRA and Springer-Verlag France 2013

\begin{abstract}
- Context The commercial feasibility of sawmilling depends on the expected volume and value of sawn planks. Models that predict the volume of sawn timber of a particular quality and produced from logs of known characteristics are therefore very useful.

- Aims The objectives were to study variation in sawing yield and to obtain models that predict lumber volume and grade recovery on the basis of easy-to-measure predictor variables of saw logs.

- Methods Forty-six oak trees growing in Galicia (NW Spain) were felled and cut into logs. The logs were visually graded and sawn mainly into quartersawn planks, which were dried, planed and visually graded for structural purposes.

- Results The total volumetric sawing yield was $47.6 \%$. The sawing yield for planks of structural dimensions (cross-section, $70 \times 120$ or $70 \times 170 \mathrm{~mm}$ ) was $43.4 \%$, but decreased to $8.4 \%$ for structural sized and quality grade beams because of wane and biotic damage in many pieces. Log grade did not significantly affect sawing yield in the sample analysed, despite the wide range of diameter over bark at the smallest end in the sampled logs $(22-77 \mathrm{~cm})$. The sawing pattern affected total sawing yield $(F=4.913 ; p$ value $=0.001)$ and the sawing yield for structural planks $(F=6.142 ; p$ value $=0.0002)$; radial sawing with one cut and live sawing of half logs provided the
\end{abstract}

Handling Editor: Jean-Michel Leban

The three authors have contributed equally in the study.

G. Riesco Muñoz $(\bowtie) \cdot$ M. Gasalla Regueiro

Departamento de Ingeniería Agroforestal, Universidad de Santiago

de Compostela, Escuela Politécnica Superior, Campus

Universitario s/n, Lugo 27002, Spain

e-mail: guillermo.riesco@usc.es

A. Remacha Gete

Escuela Universitaria de Ingeniería Técnica Forestal, Universidad Politécnica de Madrid, Avenida de Ramiro de Maeztu s/n,

28040 Madrid, Spain highest yields. Three models were proposed for estimating sawn volume in timber products, with the small-end log diameter over bark as the predictor variable and $R_{\text {adj }}{ }^{2}$ between 0.31 and 0.78 ( $p$ value $<0.01)$.

- Conclusion For the purpose of producing oak timber destined for structural use, the presence of bark and sapwood in planks must be reduced in the sawing process; this would decrease the total lumber recovery but increase the timber value yield. Air drying must be accelerated to reduce biotic damage in sawn planks. Geometric mean diameter over bark at the smallest end $(d)$ outperforms other measures as a predictor variable for total or structural sawn timber volume.

Keywords Oak wood $\cdot$ Sawing yield $\cdot$ Structural timber . Log quality

\section{Introduction}

Oak (Quercus robur L.) is widespread in temperate Europe and occurs throughout the northern Iberian Peninsula. Oak is the most extensive deciduous tree in Galicia (northwestern Spain), covering 125,000 ha in pure stands and reaching 373,000 ha in pure and mixed stands (which include other hardwoods or coniferous trees). Oak stands represent $26 \%$ of the forested area in Galicia (Área de Inventario y Estadísticas Forestales 2011). The species is also economically important, with an annual cut volume of $115,000 \mathrm{~m}^{3}$ in 2010 , most of which, i.e. $99 \%$, corresponds to products from final cuttings (Ministerio de Agricultura, Alimentación y Medio Ambiente 2010).

In Spain, oak is one of the most highly valued species for the quality of its wood, which has historically been used to produce ceiling joists, purlins and roof truss members within fabric or stone structures, because of the high mechanical strength and strong resistance to decay (Wagenführ 2007). Heartwood is the main constituent of oak wood products, 
whilst sapwood is acceptable in small proportions and for less valuable products (Riesco Muñoz 2001).

Logs are graded to identify the most suitable use for each, and the largest logs (logs more than $2.5 \mathrm{~m}$ long) with the fewest external defects are accepted by the veneer industry for decorative applications. However, the main market for domestic oak logs is the sawmilling industry, which is supplied with low-grade logs for products such as railway sleepers and, occasionally, building beams. Some sawmills produce oak flooring, barrel staves, furniture, carpentry elements, boat keels and other products with high added value (Pastor and Salgado 1999). Only $10 \%$ of the oak timber logged in Spain is suitable for cooperage (barrel manufacturing) or furniture, while $50 \%$ is suitable for railway sleepers or flooring and the remaining $40 \%$ is waste and used as fuelwood (Riesco Muñoz 2001).

The size and quality of the logs determine the sawing pattern, and both size and sawing pattern affect the yield of high-quality sawn pieces. The commercial feasibility of oak sawmilling mainly depends on the expected production yield. Therefore, models that predict the volume of sawn timber produced from logs of known size are very useful.

The aims of this study were (1) to investigate the variation in the volume of sawn timber of a specific quality produced by sawing oak logs of known dimensions and grade and (2) to construct models that predict the volume of sawn timber produced in the sawmill.

\section{Material and methods}

A sample of 46 oak trees (Q. robur L.) growing in Galicia (NW Spain; Fig. 1) was obtained. The sampling process began with the selection of 23 mature pure stands of the species at a wide range of altitudes, slopes and stand densities (Table 1). The selected stands covered the entire region (comprising an area between the coordinates $41^{\circ} 58^{\prime} 36^{\prime \prime}$ and $43^{\circ} 36^{\prime} 80^{\prime \prime}$ latitude $\mathrm{N}$, and $7^{\circ} 2^{\prime} 51^{\prime \prime}$ and $8^{\circ} 45^{\prime} 16^{\prime \prime}$ longitude W). The location of the stands covers almost the complete range of altitudes in which oak trees form stands in Spain, roughly between sea level and an altitude of 1,000 m (RodríguezCampos et al. 2010). The slopes in the sampled sites were steeper than optimal for a species that prefers smooth slopes or flat land, but the stands were located in areas where oak is usually found in Spain. Between one and five trees were felled in each stand. The stems were sawn and $82 \operatorname{logs}$ were obtained (Table 2).

Cross-diameter was measured at both ends of each log and the geometric mean diameter over bark at the smallest end, hereafter referred to as $d$ (Fig. 2), was calculated (Pardé and Bouchon 1988). Measurement of diameter at both ends of the $\log$ was considered equivalent to measurement of the diameter at different heights in the stem (Alder 1980) and therefore the total log over bark volume was calculated accurately by circular integration of a parabolic taper function adjusted for each $\log$. This procedure is very useful in the analysis of sawing schemes for individual logs in sawmills (Von Gadow and Hui 1999). The over bark cylindrical volume was calculated as the volume of a cylinder, the base of which was the smallest crosssection calculated for the $\log$ and the length was measured directly on the $\log$ (Fig. 2). This volume variable, which includes log diameter and log length, was used as a possible explanatory variable in models used to predict sawing yield or volume recovery. It was not merely used as a descriptor of the $\log$ shape because the use of cylinders to represent logs is a past simplification and is no longer needed (Harless et al. 1991). The crookedness, taper, ovality and location of the pith (cross-sectional pith eccentricity) were also determined (Fig. 2). The width of annual growth rings was calculated for the smallest end of the $\log$, as the dimension of the longest radial segment in the section divided by the number of rings.

Each log was visually graded in accordance with the grading method defined by the Centre Technique du Bois et de l'Ameublement (CTBA) for oak logs (Baylot and Vautherin 1992). The classification specifies four quality grades (A, B, C and $\mathrm{D})$ and is based on log dimensions and visible defects. Since the grading procedure may be prone to subjectivity, all logs were graded in the sawmill by the same log grader. The visual grading of logs yielded the following frequency distribution: $9 \% \operatorname{logs}$, class A; $34 \%$, class B; $37 \%$, class $\mathrm{C} ; 13 \%$, class D; and $7 \%$ were logs of grade below class D. Although the latter class was not considered acceptable for sawing, these $\operatorname{logs}$ were also sawn and included in later parts of the study to help produce more general prediction models.

Most of the logs selected were from the butt part of 6-m lengths of the stems: $52 \%$ butt logs, $34 \%$ second logs, $11 \%$ third logs and $3 \%$ fourth logs. The position of the log along the stem was not analysed further as a possible predictor variable for sawing yield because the original log height in the tree is not easily determined in the sawmill yard. Nonetheless, the qualitative variable butt/not butt $\log$ is easily recognised by the buttresses and the chainsaw directional notch in the biggest end of the log.

Milling of the logs was carried out in only one industrial sawmill to avoid any variation in processing due to the mill, such as the influence of technological features of the sawbench, operator skill in managing the headrig and experience of the sawyer with hardwoods. The sawmill setup comprised a single vertical band headsaw, with the kerf size fixed at $4 \mathrm{~mm}$. Some planks and flitches were reprocessed (trimmed off, deep cut and crosscut) out of the headrig to remove defects, thus salvaging some parts.

The objective of the sawing was to provide the largest number of quartersawn or at least partly quartersawn planks of target dimensions $70 \times 170 \times 3,000$ or $70 \times 120 \times 2,000 \mathrm{~mm}$. These were the preferred pieces in this study because the 
Fig. 1 Location of the sample stands of oak trees, plotted on the map showing all the council regions in Galicia (NW Spain)

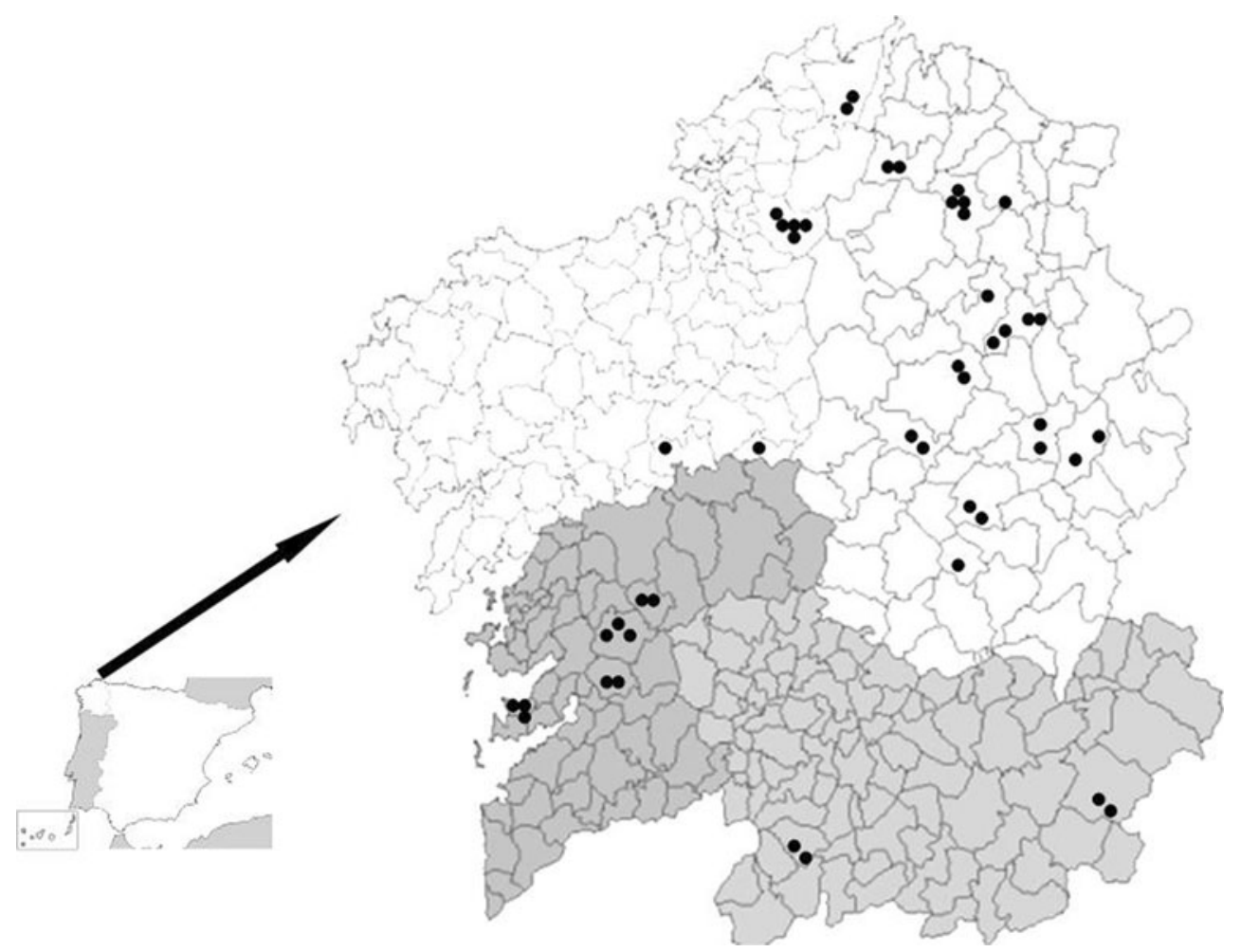

(types $1-4$, in Fig. 3). Radial sawing involved making one to three rip cuts that were parallel to the log axis, parallel to each other, and approximately radial. In each of the (one or two) central un-edged boards thus obtained, usually $70 \mathrm{~mm}$ thick, cuts were made perpendicular to the un-edged board face to produce planks of width 170 or $120 \mathrm{~mm}$. The two initial side half logs were live sawn with approximately radial cuts to

Table 2 Characteristics of the sawn $\operatorname{logs}(n=82)$

\begin{tabular}{|c|c|c|c|c|}
\hline & Mean & Min & Max & $\mathrm{CV} \%$ \\
\hline Length, $\mathrm{cm}$ & 299 & 216 & 357 & 7.8 \\
\hline $\begin{array}{l}\text { Geometric mean diameter over bark at } \\
\text { the smallest end, } \mathrm{cm}\end{array}$ & 37.4 & 22.5 & 76.6 & 24.2 \\
\hline $\begin{array}{l}\text { Geometric mean diameter inside bark } \\
\text { at the smallest end, } \mathrm{cm}\end{array}$ & 31.3 & 22.3 & 42.9 & 14.6 \\
\hline Bark thickness, mm & 12.8 & 7.5 & 25.5 & 33.9 \\
\hline Sapwood width, cm & 4.1 & 2.5 & 7.0 & 39.3 \\
\hline Over bark volume, $\mathrm{dm}^{3}$ & 414.9 & 121.3 & $1,201.7$ & 47.5 \\
\hline Over bark cylindrical volume, $\mathrm{dm}^{3}$ & 350.5 & 93.9 & $1,414.8$ & 56.2 \\
\hline Crookedness, $\%$ & 15.1 & 0.0 & 57.4 & 78.6 \\
\hline Taper, \% & 2.9 & 0.0 & 10.3 & 68.3 \\
\hline Ovality, \% & 116.7 & 100.0 & 150.8 & 10.7 \\
\hline Pith eccentricity, $\%$ & 7.6 & 1.6 & 31.1 & 66.5 \\
\hline Bark in the log volume, $\%$ & 13.5 & 7.7 & 23.6 & 21.2 \\
\hline Heartwood in the log volume, $\%$ & 52.4 & 31.7 & 76.1 & 19.5 \\
\hline
\end{tabular}

$n$ number of observations, $C V \%$ coefficient of variation, i.e. the quotient between standard deviation and mean, expressed as percentage 


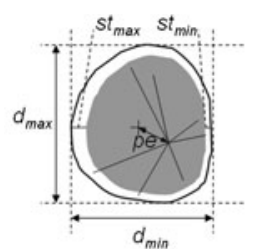

$$
\begin{aligned}
& \text { geometric mean diameter over } \quad d=\sqrt{d_{\max } d_{\min }} \\
& \text { bark at the smallest end } \\
& \text { ovality }(\%)=\frac{d_{\max }}{d_{\min }} 100 \\
& \text { ovality CTBA (\%) }=\frac{d_{\max }-d_{\min }}{d_{\min }} 100 \\
& \text { sapwood thickness }=\frac{s t_{\max }+s t_{\min }}{2} \\
& \text { pith eccentricity }=\frac{p e}{d} 100
\end{aligned}
$$
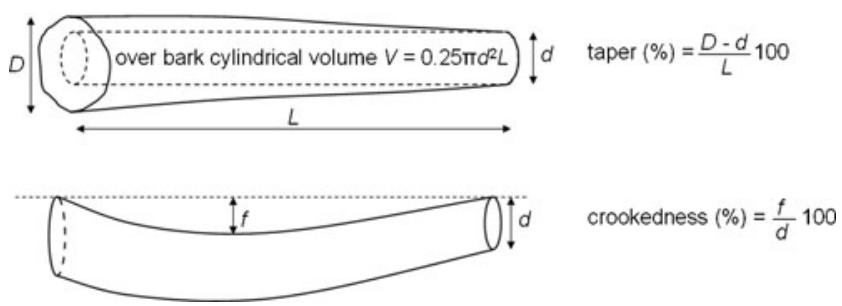

Fig. 2 Schematic diagram of practical procedure for measuring log shape and size

produce planks of structural dimensions. The initial sawline in half logs was visually located with the aim of recovering a first board face of at least the minimum acceptable width and of the maximum allowable length and wane width for structural grade planks (Steele et al. 1993). In the largest logs, the sawing pattern was tangential, i.e. the log was slabbed and the resulting four-sided canton was resawn (type 5, in Fig. 3).

The log breakdown provided 658 sawn pieces (Table 3). The green volume of each structural size plank obtained was calculated by measuring length, width and thickness (precision, $1 \mathrm{~mm}$ ). The pieces were piled up for slow air-drying (746 days on average, ranging 302-910), thus avoiding the usual distortions and checks that occur in oak wood during kiln drying. Once the drying process was complete, the planks were planed up to $1 \mathrm{~cm}$ from each face and trimmed in the butt to the definitive dimensions for visual grading $(50 \times 150 \times 3,000$ or $50 \times 100 \times 2,000 \mathrm{~mm}$ ) to remove end splits and other defects formed during sawing, piling and drying. The dried and planed beams (spars) were visually graded in accordance with Spanish standard UNE 56544:2011 developed for softwood structural timber. This standard has been shown to be effective for predicting the mechanical performance of oak timber in the absence of a specific Spanish standard for oak (Riesco Muñoz et al. 2011). That study reported that other visual grading standards exhibited poorer performance than Spanish standard UNE 56544:2011 for predicting the structural aptitude of oak beams. The standard defines three types of planks: top quality planks (ME-1), second quality planks (ME-2) and rejected planks.

In the current version of the EN 1912:2012 standard, the visual Spanish grades (ME-1 and ME-2) for oak wood are not still assigned to the European strength classes system (EN 338:2010). However, Riesco Muñoz et al. (2011) suggested a preliminary assignation of visual grade ME-2 to European strength class D40.

Four sawing yield variables were considered in the study:

- $\quad$ total green volume of sawn timber, divided by the over bark volume of log and expressed as a percentage

- green volume of structural size sawn timber $(70 \times 120 \times$ 2,000 or $70 \times 170 \times 3,000 \mathrm{~cm}$ ), divided by the over bark volume of log and expressed as a percentage

- green volume of structural size and ME-1 sawn timber, divided by the over bark volume of log and expressed as a percentage

- green volume of structural size and ME-2 sawn timber, divided by the over bark volume of log and expressed as a percentage

One-way analysis of variance was applied to search for significant differences among means of data grouped by the qualitative variables of log grade, sawing pattern and position along the stem. Exploratory analysis of relationships between quantitative log variables was carried out by graphical presentation of the plotted pairs and by means of the Pearson's linear correlation coefficient $(R)$. These analyses were performed for the total log data and also separately for each sub-sample of logs grouped by log quality grade, sawing pattern or position in the stem. After selection of the log variables most closely related to the four sawing yield variables, regression equations were fitted by ordinary least square regression. Elucidation of the most suitable linear models depended on numerical analyses of the residuals, based on examination of adjusted

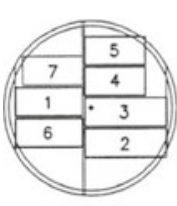

Type 1

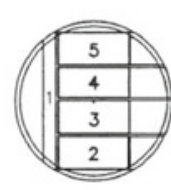

Type 2

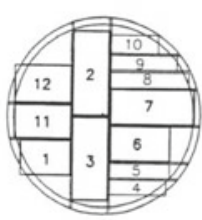

Type 3

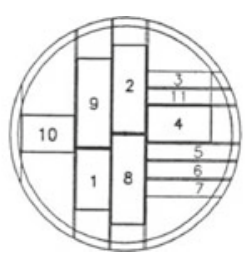

Type 4

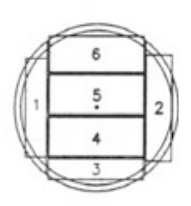

Type 5
Fig. 3 Examples of the sawing schemes used on the sawlog cross sections. The scales of the figures are approximately equal. Type 1 radial sawing pattern with one cut and live sawing of both half logs. Type 2 radial sawing pattern with two cuts to obtain one flitch and live sawing of one half log. Type 3 radial sawing pattern with two cuts and live sawing of both half logs. Type 4 radial sawing pattern with three cuts and live sawing of both half logs. Type 5 tangential sawing pattern to obtain two flitches and a variable number of planks 
Table 3 Mean characteristics of sawn pieces $n$ number of observations

${ }^{a}$ Not structural size pieces, of variable length and width

${ }^{\mathrm{b}}$ Sound and unsound knots not distinguished, according to UNE 56544:2011 standard; ME1 and ME-2, top and second grade plank for structural uses, according to UNE 56544:2011 standard

\begin{tabular}{llll}
\hline & \multicolumn{3}{l}{ Rough dimensions, $\mathrm{mm}$} \\
\cline { 2 - 4 } & $\begin{array}{l}70 \times 120 \times 2,000 \\
(n=151)\end{array}$ & $\begin{array}{l}70 \times 170 \times 3,000 \\
(n=326)\end{array}$ & $\begin{array}{l}\text { thickness } 20-50^{\mathrm{a}} \\
(n=181)\end{array}$ \\
\hline Green width, cm & 12.3 & 17.2 & 9.8 \\
Green thickness, cm & 6.3 & 7.0 & 3.6 \\
Ring width, mm & 3.5 & 4.2 & \\
General slope of grain & 0.04 & 0.03 & \\
Maximum diameter of face knot ${ }^{\mathrm{b}}, \mathrm{cm}$ & 2.8 & 4.7 & \\
Maximum diameter of edge knot ${ }^{\mathrm{b}}, \mathrm{cm}$ & 1.8 & 2.5 & \\
Maximum length of checks, cm & 24 & 39 & 20 \\
Maximum length of bark pockets, cm & 38 & 3.6 & \\
Maximum width of edge wane, cm & 2.6 & 57 & \\
Maximum length of wane, cm & 69 & 0.8 & 1.0 \\
Bow, cm & 0.9 & 1.1 & \\
Spring, cm & 0.6 & 0.3 \\
Twist, cm & 0.5 & 1.2 \\
Cup, cm & 0.5 & 19.4 \\
Percentage of pieces of ME-1 quality & 3.6 & 79.4 \\
Percentage of pieces of ME-2 quality & 17.9 & 78.5 & \\
Percentage of pieces excluded as strength grades & & & \\
\hline
\end{tabular}

determination coefficient $\left(R_{\mathrm{adj}}{ }^{2}\right)$, relative bias $(E \%)$, relative root mean square error (RMSE\%) and visual inspection of residual plots. All statistical analyses were carried out with IBM SPSS Statistics software (version 20).

\section{Results and discussion}

\subsection{Log quality and sawing yield}

The volume of sawn pieces was on average $47.6 \%$ of the over bark volume of logs, and it decreased slightly to $43.4 \%$ when only the pieces of structural dimensions were considered (Table 4). The volume of sawn pieces decreased slightly to $43.4 \%$ when only pieces of structural dimensions were considered. The sawing yield of structural grade beams (planks of quality ME-1 or ME-2, defined in accordance with the UNE 56544:2011 standard) was low (8.4\% of the over bark volume). Recovery of pieces within the strictest grade was very low, although the diameter and shape of the sampled logs were within the usual range for raw material in hardwood sawmills. Additionally, the coefficients of variation for sawing yield of structural quality planks were very high (Table 4), relative to the lower size dispersion in the sampled material (trees in Table 1 and logs in Table 2). Therefore, ME-1 and ME-2 were grouped together and are hereafter considered as "structural grade planks" for modelling purposes.

The reasons for rejecting planks for structural use, in accordance with the visual grading standard applied (UNE 56544:2011), are shown in Fig. 4. This highlights the importance
Table 4 Descriptive statistics of sawn timber volume and sawing yield by grade $(n=82 \operatorname{logs})$

$\mathrm{N}$ number of observations; $\mathrm{CV} \%$ coefficient of variation, i.e. the quotient between standard deviation and mean, expressed as percentage; $M E-1$ top quality plank according to UNE 56544:2011 standard; $M E-2$ second quality plank according to UNE 56544:2011 standard

\begin{tabular}{lllll}
\hline & Mean & Min & Max & CV\% \\
\hline Total sawn timber volume, dm ${ }^{3}$ & 199.5 & 17.6 & 720.5 & 61.0 \\
Structural size of sawn timber volume, dm ${ }^{3}$ & 183.5 & 17.6 & 720.5 & 65.9 \\
ME-1 quality and struct. size of sawn timber vol., $\mathrm{dm}^{3}$ & 3.4 & 0.0 & 89.5 & 397.8 \\
ME-2 quality and struct. size of sawn timber vol., dm $\mathrm{dm}^{3}$ & 37.7 & 0.0 & 410.8 & 201.5 \\
Total sawing yield, \% & 47.6 & 10.5 & 81.4 & 32.6 \\
Structural size timber sawing yield, \% & 43.4 & 10.5 & 81.4 & 38.1 \\
Struct. size timber and ME-1 quality sawing yield, \% & 0.9 & 0.0 & 41.7 & 520.9 \\
Struct. size timber and ME-2 quality sawing yield, \% & 7.5 & 0.0 & 59.7 & 157.6 \\
\hline
\end{tabular}


of wane and damage caused by active biotic attack as reasons for rejection. The limits for wane in the Spanish standard coincide with the requirement for maximum allowable wane expressed in the European standard EN 14081-1:2006 for visual grading methods. Therefore, a more restricted limit for wane size in the national standard would probably lead to a plank rejection rate higher than the $31 \%$ obtained in this study. The frequent occurrence of wane and biotic damage as a cause of exclusion is partly attributable to the sawing procedure, in which a small quantity of bark and sapwood was allowable in the planks, with wane appearing in the former and the latter displaying poor resistance to fungal and insect attack. As a result, during the long air drying stage, the sapwood was damaged by insects, with Lyctus brunneus Steph., Phymatodes testaceus L. and Xyleborus dispar $\mathrm{F}$. the most frequently detected species.

The magnitude of bark or sapwood is easy to check externally on the $\log$ before sawing. The sawyer can use this information to choose the best sawing method and log orientation. If the sawing cuts remove wane and sapwood in sawn pieces, or logs are debarked prior to sawing, knots and bark pockets become the most frequent reasons for rejection (Fig. 4), although unfortunately neither type of defect is easy to detect on the log surface.

The four types of distortion (bow, spring, cup and twist) were less frequent reasons for rejection (Fig. 4) because the timber was piled up and dried slowly. In addition, most of the graded pieces were quartersawn planks and this type of timber is dimensionally more stable during drying (Sandberg 2005), although it dries more slowly because water readily passes through in a radial direction. Therefore, distortions can be left out to classify air-dried quartersawn oak timber (the possibility of excluding distortions of the grading rules is already included in the UNE 56544:2011 standard).

The sawing yields were similar to those obtained for other hardwoods (Pastor and Salgado 1999; Tuset and Durán 1986)

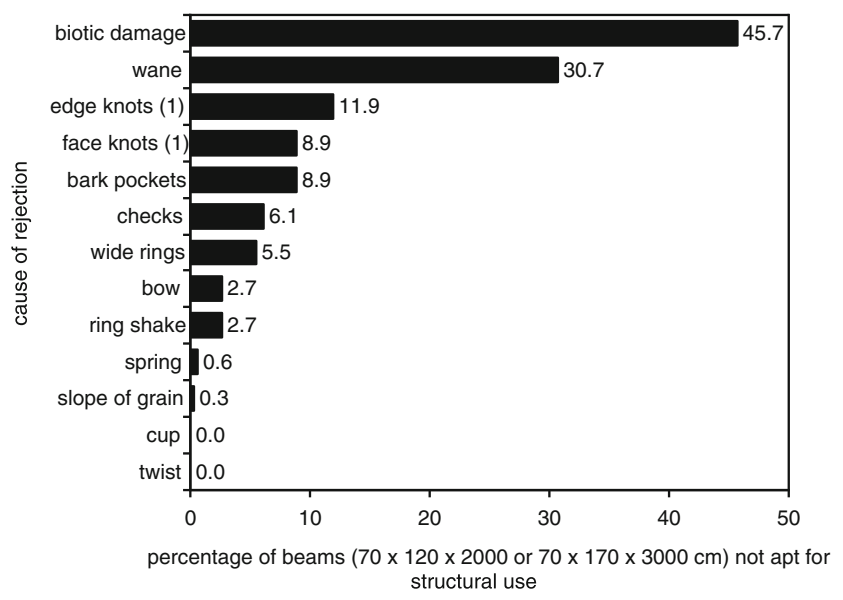

Fig. 4 Causes of rejection of planks for structural use when visually graded in accordance with the UNE 56544:2011 standard. ${ }^{(1)}$ Sound and unsound knots were not distinguished and intermediate in comparison with those reported for industrial sawmilling conditions (Table 5). Some variables were intentionally maintained constant (kerf size), almost constant (log length) or were objectively selected (for details of $\log$ orientation and position of the first opening face, see Section 2) in order to reduce their influence as sources of variation in the sawing yield, and therefore the huge variation in sawing yield was unexpected. In fact, a small increase in sawing yield due to decreased kerf size has been reported (Thomas 1999). Log length affects sawing yield as previously reported for oak (Hamner et al. 2007). The impact of log orientation on hardwood sawing yield varies between 9 and $11 \%$ for the best and worst $\log$ orientation (Harless et al. 1991; Steele et al. 1993). Finally, the position of the first opening face from the log axis slightly influences the volume recovery (Steele et al. 1989).

Sawing so that bark and sapwood were excluded from sawn planks would lead to rejection of fewer structural pieces at the expense of a reduction in the usable volume of the logs. Bark and sapwood made up 13.5 and $34.1 \%$ of the $\log$ volume, on average, and therefore only $52.4 \%$ was heartwood (Table 2). The amount of sapwood in the sampled logs, in terms of thickness and volume, was higher than reported in other studies (Bary-Lenger and Nebout 1993; Bues and Schulz 1990; Collardet and Besset 1992; Deret-Varcin 1983; Mayer-Wegelin 1951; Wagenführ 2007).

Preservatives can be applied to the timber surface, by brushing or briefly dipping the planks prior to the drying stage, to reduce the impact of insect attack as a cause of rejection of sawn planks in structural grading. However, such treatments are not effective on wet pieces, such as freshly sawn planks. It may also be possible to speed up natural drying or to use artificial drying or a mixed process combining forced and natural drying. Air drying can be accelerated by piling planks with larger spaces between the planks in each line and using larger fans to force air through piles and also by separating the piles from each other. During kiln drying, the air conditions in the kiln are modified depending on changes

Table 5 Volumetric sawing yields of different hardwoods reported in different studies

\begin{tabular}{lll}
\hline Type of wood & Yield, \% & Source \\
\hline Oak (diameter 24-46 cm) & $25-42$ & $\begin{array}{c}\text { Bary-Lenger and Nebout } \\
(1993)\end{array}$ \\
Galician hardwoods & 45 & $\begin{array}{l}\text { Pastor and Salgado (1999) } \\
\text { Eucalyptus sp. }\end{array}$ \\
$\begin{array}{l}\text { Q. robur and Quercus petraea } \\
\text { Hardwoods }\end{array}$ & $50-55$ & Tuset and Durán (1986) \\
Q. robur and Q. petraea & 60 & Tuset and Durán (1986) \\
Hardwoods & & Nylinder and Woxblom \\
& $65-70$ & Sandberg (2005) \\
\hline
\end{tabular}


in the current wood moisture content over time. Although the drying process speeds up at high temperatures, there is a greater risk of drying defects occurring when more intense (faster) drying schedules are used. Faster drying will cause more checks and distortions (mainly twist) due to the natural instability of oak wood (e.g. Wagenführ 2007). Other defects such as wood collapse, darkening and strength reduction may occur in oak as a result of forced drying (Skuratov 2008). Therefore, more planks would be rejected during grading, although only slightly more because quartersawn planks are stabler in response to drying. Furthermore, the extent and intensity of biotic damage, which mainly affects wet wood, would decrease because accelerated drying mainly affects the sapwood, the most sensitive part of wood in terms of biotic damage. Hence, a greater proportion of planks would be considered suitable for structural use.

The recognised importance of age of the trees in the abundance of sapwood, reported by Collardet and Besset (1992), prompted us to study the influence of tree age in the recovery of structurally graded planks from logs. In older trees, the proportion of sapwood in the log volume is smaller and therefore the presence of biotic damage and plank rejection in grading is also expected to be lower. However, knot size and tree size are positively related at stand level and knottiness may become a more frequent reason for rejecting planks derived from the largest trees. The mechanical performance of French oak beams, similar in size to those in the present study, was found to decrease when the beams were obtained from the thickest stems, and more planks derived from trees of breast height diameter over $60 \mathrm{~cm}$ than planks derived from smaller trees were rejected (Lanvin et al. 2007). On the basis of the relatively small sample analysed in the present study, the proportion of rejected planks was significantly lower $(F=21.084 ; p$ value $=0.00002)$ in logs from trees over 74 years old (an average of $29 \%$ of lumber volume rejected per log in trees over 74 years old and $41 \%$ of volume rejection in trees under that age). Therefore, an additional way of mitigating the presence of biotic damage on sawn pieces, and thus improving the yield of structural graded planks, is to saw logs from adult trees (age equal or above 74 years old, corresponding approximately to breast height diameter $43 \mathrm{~cm}$ in the sample).

The yield depends on the position of internal defects and their abundance in the log and precise knowledge about the location of defects is therefore required. The sawyer uses external defect in logs (e.g. branch scars) as initial indicators of the number and location of internal defects. As the sawing starts and fresh sawn faces are exposed, the defects provide further information that helps the sawyer obtain the maximum timber yield. However, once a sawn face is exposed, the decision about $\log$ orientation has already been made and cannot be reversed in light of the information obtained from the new face. The application of non-destructive techniques such as computed axial tomography makes it possible to scan timber and to measure and locate interior defects with the aim of applying the most efficient sawing pattern based on the precise knowledge of the location of defects and defect-free regions inside the log (Harless et al. 1991; Steele et al. 1993). Medical CT scanning devices provide digital images of sufficiently high resolution to enable detailed information concerning internal singularities (mainly pith and knots) to be obtained. However, if the scanning and image processing speed are adapted to the flow of logs in the sawmill (ultrafast configuration), the resolution along the feeding direction is not sufficient to detect small defects or annual rings (Wei et al. 2011). CT scanners built specifically for the wood industry are now available and implemented in some sawmills (Longuetaud et al. 2012). As knottiness affects both the strength and the aesthetic grade of oak beams, oak logs are scanned by CT to detect knot characteristics (location, inclination, maximum diameter, length and volume) and thus enable estimation of the maximum amount of quality lumber recovery (Lanvin et al. 2007). X-ray computed tomography combined with optical three-dimensional scanning measurements and software tools for the analysis of digital images provide very accurate automatic detection of knots in oak logs and beams (high rate of detected knots and low rate of false alarms). However, the presence of sapwood in the log also affects the decision regarding the best sawing pattern and the lumber value of oak, sugar maple, yellow poplar and other hardwoods, in which appearance is more important than strength properties (Johansson 2008). Unfortunately, the automatic location of sapwood boundaries in digital images has not yet been resolved, partly because of the drawback in distinguishing sapwood and other features from wet wood areas in CT digital slices (Longuetaud et al. 2012; Wei et al. 2011).

The mean values of the four sawing yield variables analysed in the present study were highest in the grade A logs. Top class logs (A) are those of highest quality ( $d$ equal or above $45 \mathrm{~cm}$, sapwood width lower than $30 \mathrm{~mm}$, ring width lower than $4 \mathrm{~mm}$, etc.) and are suitable for the veneer industry, cabinet making and cooperage. The mean values of the four variables were lowest in logs of grade $\mathrm{D}$ and below. The sawing yield of structural grade beams (quality ME-1 or ME-2) tended to decrease: $14.2,9.2,7.7,6.7$ and $5.3 \%$ for $\log$ grades A, B, C, $\mathrm{D}$ and rejected, respectively. However, the analysis of variance revealed that the mean sawing yield does not differ significantly among $\log$ grades, assigned according to the CTBA method (Baylot and Vautherin 1992). This result (partly attributable to the limited number of logs sampled in extreme grades) was unexpected because the CTBA grading method is specific for Q. robur logs and is based on a very detailed recording of shape and dimension parameters, which theoretically affect the sawing yield of the log. Unfortunately, in addition to its poor predictive value of the sawn timber yield, the CTBA log grading method involves a number of subtle parameters and is therefore difficult to use directly in the industry. 
Furthermore, a supply policy based on the acquisition and manufacture of high-quality $\operatorname{logs}$ in order to maximise the volume or value of sawn products is not advisable in the sawmill. If the sawing industry processes high-quality logs, it will compete with the veneer slicing industry for the same raw material because the requirements for high-quality logs are similar in both industries. Although some studies have reported that higher-grade red oak logs produce higher sawn yield (e.g. Lin et al. 1994), the increased cost of acquiring high-grade logs must be taken into account, resulting in a truly lower profitability of better logs, despite the higher yield of high-value solid wood products. In other words, yield and profit are not necessarily the same (Johansson 2008; Lin et al. 1994; Steele et al. 1993).

The sawing pattern significantly affected the total sawing yield $(F=4.913 ; p$ value $=0.001)$ and the sawing yield of structural planks of cross-section $70 \times 120$ or $70 \times 170 \mathrm{~mm}$ $(F=6.142 ; p$ value $=0.0002)$. This may be attributed to the fact that the type of sawing partly depends on the log diameter, mainly in logs less than $3 \mathrm{~m}$ long $(n=13)$, and therefore diameter had an indirect effect on yield. The mean sawn timber yield for each sawing pattern is shown in Table 6 .

\subsection{Factors and models for sawing yield}

The correlation matrix partly shown in Table 7 indicates highly significant and close correlations only between the sawn plank volume and $d$, bark thickness and log volume. $R$ was higher for total log volume than for cylindrical volume. Variables related to the shape of the $\log$ (crookedness, sapwood width, ovality, pith eccentricity) were not significantly related to the volume of sawn planks, even when sorted by grades. There were no significant or close correlations between the volume of sawn planks of a certain quality and the dimensions of the log.

These results suggest that a predictive model for sawn timber volume must include $d$ (geometric mean diameter over bark at the smallest end) as the predictor variable because the remaining variables that are closely related to the sawn timber volume (geometric mean diameter inside bark at the smallest end, total log volume, cylindrical log volume) are more difficult to measure on the log. The possibility of using bark thickness as an additional predictor variable was ruled out in order to prevent autocorrelation effects because diameter and bark thickness were highly and significantly correlated $\left(R=0.54^{* *}\right)$.

Sawn timber volume is not influenced by only one variable, and some combinations of variables accurately predict the volume of sawn timber that will be obtained from one log. Some of these variables, such as the log dimensions studied, can be easily quantified. However, quantification of other variables, such as widespread rot in the log and bifurcation (which greatly reduce the merchantable timber volume in the log), may be cumbersome. Because of the influence of these defects on the sawn product yield, visual grading of logs integrates all features that affect the sawing yield. However, in the sample analysed, log grading did not have a significant effect on sawing yield, as already indicated.

Analysis of plotted data (diameter, sawn volume) aimed to remove the data for one particular log, the largest in the sample, for which the sawn volume was exceptionally small and, inversely, diameter was too large for a sawlog (Fig. 5). This unusual observation would exert an undue influence on the estimated parameters of the models. Omitting such observation is undesirable but assumable for sample size (Zuur et al. 2010).

Several linear equations were tested for fitting sawn volume (total or structural size) as a dependent variable and $d$ (log diameter) as an independent variable. The result of such model searches (data not shown) revealed that the goodnessof-fit was not any better when each group of logs (all of the same grade, all with the same sawing pattern, or all butt/not butt logs) was considered separately. General models for the whole samples of logs were therefore fitted. Among the equations considered, first-, second- and third-order polynomials provided the best fits as determined by goodness-of-fit parameters. Thus, the adjusted determination coefficient was highest and the relative root mean square error was lowest for the second-order polynomial. This occurred in all three fits (total sawn volume versus log diameter, structural size sawn volume vs. $\log$ diameter and structural grade sawn volume vs. $\log$ diameter). Additionally, relative bias was low for the secondorder polynomial if compared with the other equations tested.
Table 6 Sawing yield and size of logs in each sawing pattern $(n=82 \operatorname{logs})$

\section{Sawing pattern Number of $\operatorname{logs} \quad$ Mean values}

\begin{tabular}{|c|c|c|c|c|}
\hline & & $\begin{array}{l}\text { Diameter over bark in } \\
\text { the smallest end, } \mathrm{cm}\end{array}$ & $\begin{array}{l}\text { Total sawing } \\
\text { yield, } \%\end{array}$ & $\begin{array}{l}\text { Sawing yield in planks of } \\
\text { cross-sections } 70 \times 120 \mathrm{~mm} \\
\text { or } 70 \times 170 \mathrm{~mm}, \%\end{array}$ \\
\hline 1 & 7 & 44.4 & 59.6 & 55.3 \\
\hline 2 & 15 & 32.9 & 42.9 & 39.9 \\
\hline 3 & 23 & 35.0 & 40.7 & 33.9 \\
\hline 4 & 12 & 42.5 & 44.2 & 40.6 \\
\hline 5 & 25 & 37.8 & 55.1 & 52.3 \\
\hline
\end{tabular}

Sawing patterns $1-4$, simplified radial sawing pattern; type 5 , tangential sawing pattern 
Table 7 Pearson's linear coefficients of correlation $(R)$ among dimensional variables of the logs n.s. not significant, $M E-1$ top grade plank for structural use in accordance with UNE

56544:2011 standard, $M E-2 \mathrm{sec}$ ond grade plank for structural uses in accordance with UNE 56544:2011 standard ${ }^{*} p \leq 0.050$ significance; $* * p=0.010$, significance

\begin{tabular}{|c|c|c|c|c|}
\hline & \multicolumn{4}{|c|}{ Sawn volume } \\
\hline & \multirow[t]{2}{*}{ Total } & \multicolumn{3}{|c|}{ Cross-section $70 \times 120$ or $70 \times 170 \mathrm{~mm}$} \\
\hline & & Total & $\begin{array}{l}\text { Structural } \\
\text { grade ME-1 }\end{array}$ & $\begin{array}{l}\text { Structural } \\
\text { grade ME-2 }\end{array}$ \\
\hline Length & $0.26^{*}$ & $0.26^{*}$ & $-0.31 * *$ & n. s. \\
\hline $\begin{array}{l}\text { Geometric mean diameter over bark } \\
\text { at the smallest end }\end{array}$ & $0.76^{* *}$ & $0.74 * *$ & n. s. & $0.40^{* *}$ \\
\hline $\begin{array}{l}\text { Geometric mean diameter inside bark } \\
\text { at the smallest end }\end{array}$ & $0.77 * *$ & $0.68 * *$ & n. s. & n. s. \\
\hline Bark thickness & $0.52 * *$ & $0.54 * *$ & n. s. & n. s. \\
\hline Width of sapwood & n. s. & n. s. & n. s. & n. s. \\
\hline Log over bark volume & $0.85 * *$ & $0.84 * *$ & n. s. & $0.54 * *$ \\
\hline Log over bark cylindrical volume & $0.71 * *$ & $0.69 * *$ & n. s. & $0.39 * *$ \\
\hline Crookedness & n. s. & n. s. & n. s. & n. s. \\
\hline Taper & $0.28 *$ & $0.26^{*}$ & n. s. & $0.31 * *$ \\
\hline Ovality & n. s. & n. s. & n. s. & n. s. \\
\hline Pith eccentricity & n. s. & n. s. & n. s. & n. s. \\
\hline
\end{tabular}

The second-order polynomial, i.e. the complete parabolic Eq. (1), was therefore chosen to construct the prediction models:

$\mathrm{vi}=\mathrm{bi}_{0}+\mathrm{bi}_{1} \cdot d+\mathrm{bi}_{2} \cdot d^{2}$

where

vi

sawn timber volume of dimension and grade $\mathrm{i}$ (in cubic decimeter)

$\mathrm{bi}_{0}, \mathrm{bi}_{1}$ and $\mathrm{bi}_{2}$ fitting parameters

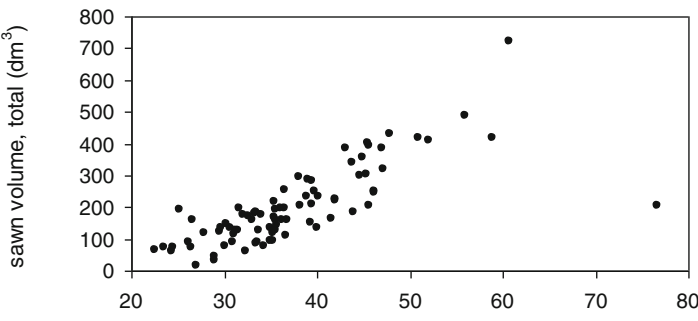

geometric mean diameter over bark at the smallest end $(\mathrm{cm})$

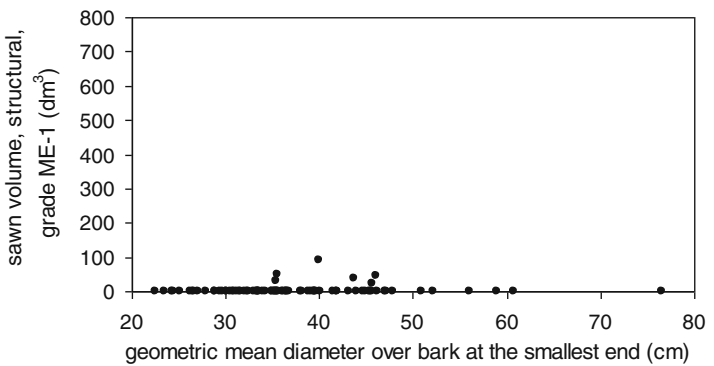

geometric mean diameter over bark in the smallest end (in centimeter)

Equations (2), (3) and (4) describe the fitted models, which are summarised in Table 8 and Fig. 6. The predictor models represent a useful tool for evaluating logs in terms of their probability to be converted into sawn planks of assorted quality. The least accurate results were obtained with model (4), for which the values of adjusted determination coefficient $\left(R_{\mathrm{adj}}{ }^{2}\right)$, $E \%$ and $\mathrm{RMSE} \%$ were low because the value of the dependent

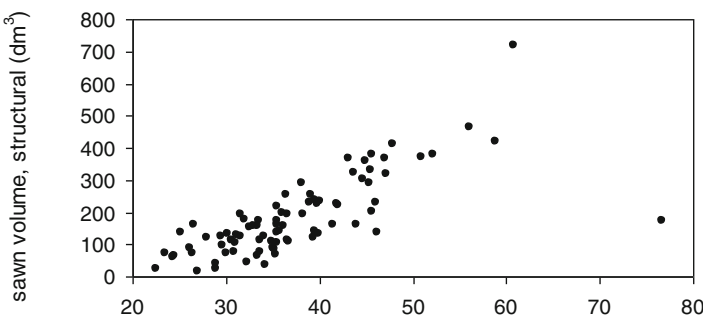

geometric mean diameter over bark at the smallest end $(\mathrm{cm})$

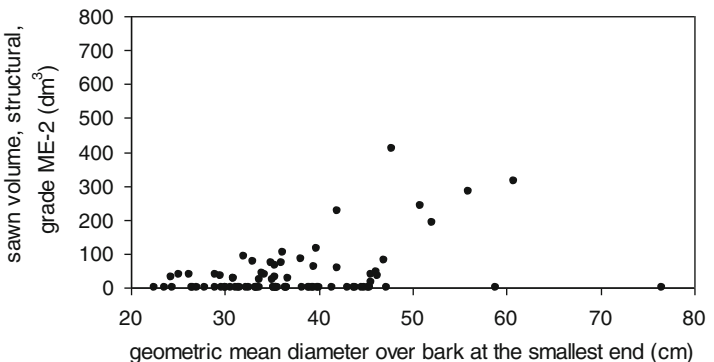

Fig. 5 Plotted pairs of volume of lumber sawed from each $\log$ (total, structural size, structural grade ME-1 and structural grade ME-2 volume) versus $\log$ diameter $d$ (geometric mean diameter over bark at the smallest end) 
variable was nil for many sawn logs (none of the sawn planks in the $\log$ were of sufficiently high quality for structural purposes).

The validity of models (2) and (3) was not extrapolated far beyond the original data; it was only defined for $d$ values in the range of diameters of the logs sampled and used in the modelling (22.5-60.8 cm). However, Eq. (4) is only defined for $d$ values in a narrower range $(28.4-60.8 \mathrm{~cm})$ because the slope of the equation decreases for smaller values.

Once the complete models have been constructed, assessment of their validity is often needed to ensure that the predictions represent the most likely outcome in the real world (Yang et al. 2004). Moreover, although the behaviour of the functions for the predictor variable within the model plays an important role in determining the overall outcome, which is usually considered more important in practice, the validity of each individual component does not guarantee its validity. Therefore, the overall model outcome must also be evaluated. The only method that can be regarded as a "true" validation involves examination of a new, independent dataset (Pretzsch et al. 2002; Yang et al. 2004); however, the scarcity of such data forces the use of alternative approaches. The common method of splitting the dataset in two sets in random does not provide additional information (Huang et al. 2003) and is not recommended from the point of view of parameter estimation.

Moreover, other techniques such as double cross-validation and statistical testing often provide very limited information about the predictive ability of the models (Kozak and Kozak 2003; Yang et al. 2004). Therefore, we decided to defer model validation until a new dataset is available for assessment of the quality of the predictions.

\section{Conclusions}

The range of sawn timber yield of oak logs was comparable to the yields reported in other studies. The sawn timber yield of

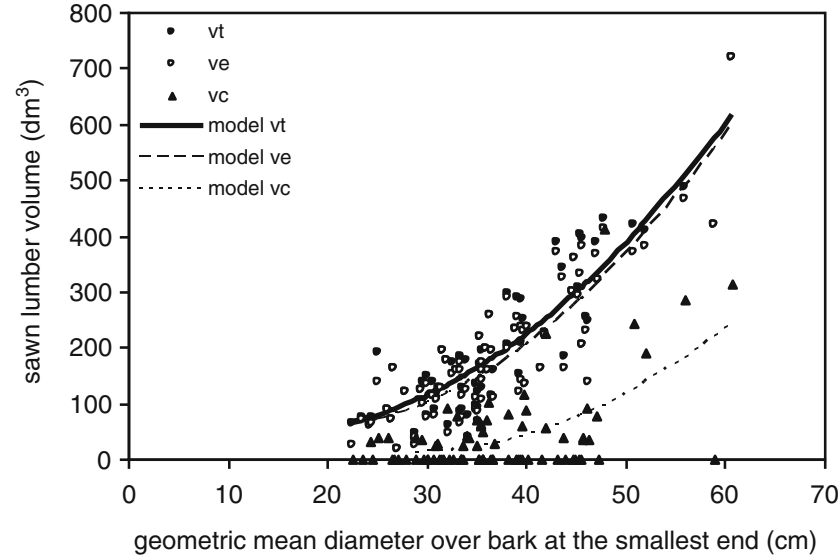

Fig. 6 Fitted models for an empirical outcome values of sawn timber volume. $v t$ total volume of pieces obtained from each log; ve volume of planks of cross-section $70 \times 120$ or $70 \times 170 \mathrm{~mm}$ obtained from each log; $v c$ volume of planks of cross-section $70 \times 120$ or $70 \times 170 \mathrm{~mm}$ obtained from each $\log$ and suitable for structural use

structural quality beams was very low, mainly because of the presence of wane and insect damage in sawn pieces. The large amount of sapwood in logs, especially in those from young trees, was the cause of frequent biotic damage in sapwood of sawn planks because of the low resistance of this type of wood to fungal and insect attack. In this study, other defects that commonly affect the structural quality of beams (knots, general slope of grain, checks, distortions etc.) were rarely causes for rejection of planks for structural use when graded in accordance with the UNE 56544:2011 standard. Furthermore, the magnitude of the distortions does not need to be considered as a grading requirement. Therefore, when sawing oak to obtain timber for structural use, the presence of bark and sapwood in the sawn pieces must be minimised; this decreases the total lumber recovery but increases the timber value yield. Air drying must also be accelerated to reduce the importance of biotic damage in sawn planks.

Table 8 Characteristics of the models for predicting the volume of sawn timber by means of the geometric mean diameter over bark at the smallest end

\begin{tabular}{|c|c|c|c|c|c|c|}
\hline Model & & Significance ( $p$ level) & $R_{\mathrm{adj}}^{2}$ & $E \%$ & RMSE\% & Coefficients \\
\hline $\mathrm{vt}=\mathrm{bt}_{0}+\mathrm{bt}_{1} \cdot d+\mathrm{bt}_{2} \cdot d^{2}$ & (2) & $<0.001$ & 0.78 & -0.24 & 28.6 & $\begin{aligned} \mathrm{bt}_{0} & =100.302 \\
\mathrm{bt}_{1} & =-7.450 \\
\mathrm{bt}_{2} & =0.263\end{aligned}$ \\
\hline $\mathrm{ve}=\mathrm{be}_{0}+\mathrm{be}_{1} \cdot d+\mathrm{be}_{2} \cdot d^{2}$ & (3) & $<0.001$ & 0.76 & 0.31 & 32.3 & $\begin{array}{l}\mathrm{be}_{0}=129.509 \\
\mathrm{be}_{1}=-9.510 \\
\mathrm{be}_{2}=0.284\end{array}$ \\
\hline $\mathrm{vc}=\mathrm{bc}_{0}+\mathrm{bc}_{1} \cdot \mathrm{d}+\mathrm{bc}_{2} \cdot d^{2}$ & (4) & $<0.001$ & 0.31 & 0.44 & 147.0 & $\begin{array}{l}\mathrm{bc}_{0}=188.537 \\
\mathrm{bc}_{1}=-12.467 \\
\mathrm{bc}_{2}=0.220\end{array}$ \\
\hline
\end{tabular}

$v t$ total sawn timber volume, in $\mathrm{dm}^{3} ;$ ve sawn timber volume with $70 \times 120 \times 2,000$ or $70 \times 170 \times 3,000 \mathrm{~mm}$ dimensions, in $\mathrm{dm}^{3} ; v c$ sawn timber volume with $70 \times 120 \times 2,000$ or $70 \times 170 \times 3,000 \mathrm{~mm}$ dimensions and suitable for structural purposes (grade ME- 1 or ME- 2 ), in $\mathrm{dm}^{3} ; d$ geometric mean diameter over bark in the smallest end, in centimeter; $b t_{0}, b t_{1}, b t_{2}, b e_{0}, b e_{1}, b e_{2}, b c_{0}, b c_{1}$ and $b c_{2}$ parameters to fit by using ordinary least square regression 
Log grading the sampled material in accordance with the CTBA did not lead to significant lumber recovery predictions. However, geometric mean diameter over bark at the smallest end $(d)$ is an objective and easy-to-measure variable in the sawmill and outperforms other measures as a predictor variable for total or structural sawn timber volume. Contrary to expectations, the predictive effectiveness of diameter was scarcely influenced by the sawing pattern used. Three models for predicting sawn timber volume, in which sawing pattern is not considered, are therefore proposed. Two models for predicting volume recovery (models 2 and 3 ) are applicable to $Q$. robur sawlogs with small-end diameter of $22-61 \mathrm{~cm}$, and one model (4) for predicting the volume recovery of structural grade planks only for logs with small-end diameter of $28-61 \mathrm{~cm}$.

In further studies, more powerful models for predicting the sawn volume of different timber grades could be constructed by including information, obtained by log scanning techniques, on sapwood location and internal log defects (mainly knots) as explanatory variables in the equations.

Acknowledgements We thank the Xunta de Galicia and the Research Office of the Universidad de Santiago de Compostela for providing financial support for the project

\section{References}

Alder D (1980) Forest volume estimation and yield prediction (vol. II). Forestry Paper 22/2. FAO, Rome

Área de Inventario y Estadísticas Forestales (2011) Cuarto Inventario Forestal Nacional. Galicia. Ministerio de Medio Ambiente y Medio Rural y Marino, Xunta de Galicia, Madrid, pp 12-25

Bartoli M, Keller R (1994) Marché et commerce du bois de chêne rouge en France. In: Timbal J, Kremer A, Le Golf N, Nepveu G (eds) Le chêne rouge d'Amérique. Institut National de la Recherche Agronomique, Paris, pp 348-352

Bary-Lenger A, Nebout JP (1993) Les chênes pédonculé et sessile en France et en Belgique. Gerfault Club. Editions du Perron, AlleurLiège, pp 120-173

Baylot J, Vautherin P (1992) Classement des bois ronds feuillus. CTBA, Paris

Bues CT, Schulz H (1990) Festigkeit und Feuchtegehalt von Eichenholz aus Waldschadensgebieten. Holz als Roh-und Werkst 48:85-89

Collardet J, Besset J (1992) Bois commerciaux (vol. II). Feuillus des zones tempérées. H Vial and CTBA, France

Deret-Varcin E (1983) Etude comparative de la qualité du bois de trois types de chênes (rouvres, pédonculés et intermédiaires), en forêt de Morimond. Ann Sci For 40:373-398

Hamner P, White M, Araman P (2007) The frequency and level of sweep in mixed hardwood saw logs in the eastern United States. For Prod J 57:23-27

Harless TEG, Wagner FG, Steele PH, Taylor FW, Yadama V, McMillin CW (1991) Methodology for locating defects within hardwood logs and determining their impact on timber-value yield. For Prod J 41:25-30

Huang S, Yang Y, Wang Y (2003) A critical look at procedures for validating growth and yield models. In: Amaro A, Reed D, Soares P (eds) Modelling forest systems. CAB, Wallingford, UK, pp 271-293
Johansson J (2008) Mechanical processing for improved products made from Swedish hardwoods. Acta Wexionensia No 157/2008. Thesis, Växjö University, Göteborg

Kozak A, Kozak R (2003) Does cross validation provide additional information in the evaluation of regression models? Can J For Res 33:976-987

Lanvin JD, Reuling D, Costrel Y, Ducerf J (2007) Evaluation of French oak for structural use. In: 1st International Scientific Conference on Hardwood Processing, Québec City, pp 61-65

Lin W, Kline DE, Araman PA (1994) Dimension yields from factory grade 2 and 3 red oak logs. For Prod J 44:19-25

Longuetaud F, Mothe F, Kerautret B, Krähenbühl A, Hory L, Leban JM, Debled-Rennesson I (2012) Automatic knot detection and measurements from X-ray CT images of wood: a review and validation of an improved algorithm on softwood samples. Comput Electron Agric 85:77-89

Mayer-Wegelin H (1951) Die Holzeigenschaften von Sumpfeiche, Roteiche und Stieleiche des Schaumburger Waldes. Forst und Holz 20:290-292

Ministerio de Agricultura, Alimentación y Medio Ambiente (2010) Anuario de Estadística Forestal 2010. Ministerio de Agricultura, Alimentación y Medio Ambiente, Madrid pp 13-46

Nylinder M, Woxblom L (2005) Industrial utilization of hardwood in Sweden. Paper presented within COST Action E42: Growing Valuable Broadleaved Tree Species

Pardé J, Bouchon J (1988) Dendrométrie (2nd ed.). ENGREF, Nancy

Pastor JC, Salgado M (1999) El fomento de la transformación de productos forestales en Galicia. In: Proceedings of the Congreso de Ordenación y Gestión Sostenible de Montes, Santiago de Compostela, vol II, pp 329-336

Pretzsch H, Biber P, Ïurský J, Von Gadow K, Hasenauer H, Kändler G, Kenk G, Kublin E, Nagel J, Pukkala T, Skovsgaard JP, Sodtke R, Sterba H (2002) Recommendations for standardized documentation and further development of forest growth simulators. Forstw Cbl 121:138-151

Riesco Muñoz G (2001) Estudio de las propiedades físico-mecánicas de la madera de roble (Quercus robur L.) de Galicia en relación con las variables del medio. Thesis, Universidad Politécnica de Madrid, Madrid

Riesco Muñoz G, Remacha Gete A, Pedras Saavedra F (2011) Implications in the design of a method for visual grading and mechanical testing of hardwood structural timber for designation within the European strength classes. Forest Systems 20:235-244. doi:10. $5424 / \mathrm{fs} / / \mathrm{fs} / 2011202-9771$

Rodríguez-Campos A, Díaz-Maroto IJ, Barcala-Pérez E, Vila-Lameiro P (2010) Comparison of the autoecology of Quercus robur L. and Q. petraea (Mattuschka) Liebl. stands in the Northwest of the Iberian Peninsula. Ann For Res 53:7-25

Sandberg D (2005) Radially sawn timber - the Primwood method for improved properties. Holz als Roh-und Werkst 63:94-101

Skuratov NV (2008) Intelligent wood drying control: problems and decisions. Dry Technol 26:585-589

Steele PH, Shi R, Wagner FG (1989) Estimation of best opening face position for asymmetric sawing patterns in hardwood logs. For Prod J 39:15-20

Steele PH, Wagner FG, Kumar L, Araman PA (1993) The value versus volume yield problem for live-sawn hardwood sawlogs. For Prod J 43:35-40

Thomas RE (1999) ROMI-RIP version 2.0: a new analytical tool for rip-first rough mill operations. For Prod J 49:35-40

Tuset R, Durán F (1986) Manual de maderas comerciales, equipos y procesos de utilización. Hemisferio Sur, Montevideo

Von Gadow K, Hui G (1999) Modelling forest development. Kluwer, Dordrecht

Wagenführ R (2007) Holzatlas. Fachbuchverlag, Leipzig

Wei Q, Leblon B, La Rocque A (2011) On the use of X-ray computed tomography for determining wood properties: a review. Can J For Res 41:2120-2140 
Yang Y, Monserud RA, Huang S (2004) An evaluation of diagnostic tests and their roles in validating forest biometrics models. Can J For Res 34:619-629
Zuur A, Ieno EN, Elphick CS (2010) A protocol for data exploration to avoid common statistical problems. Meth Ecol Evol $1: 3-14$ 